\title{
PRODUCTION, PURIFICATION AND INHIBITION OF ALGINATE LYASE FROM LOCAL ISOLATE OF PSEUDOMONAS AERUGINOSA NA11
}

\author{
R. W. Younis* \\ Lecturer \\ * Dep. of Biot. Coll. of Sci. University of Baghdad-Iraq \\ reemw812003@yahoo.com
}

\begin{abstract}
The point of this study was for determine of the optimum conditions and purification of alginate lyase from local isolate of Pseudomonas aeruginosa NA11, and inhibition of enzyme by various plant extracts. Forty local isolate s of pathogenic Pseudomonas aeruginosa were screened for their ability to produce alginate lyase. Local isolate of P.aeruginosa NA11 showed the maximum efficiency for produce of alginate lyase with high specific activity (14.4 $\mathrm{U} / \mathrm{mg}$ ). Several factors that influence on alginate lyase production from local isolate of P.aeruginosa NA11 were studied, these factors included the type of media, carbon source, nitrogen source, the incubation temperature, pH, and the incubation period. The highest yield of alginate lyase was obtained with the A medium supplemented with $0.5 \%$ of glucose and sodium nitrate at $\mathrm{pH} 7.5$ after $24 \mathrm{hr}$. incubation at $37 \mathrm{C}$. Two chromatographic techniques were used for purification of alginate lyase after precipitation by ammonium sulphate with saturated ratio (0-70 \%), including, ion exchange chromatography by DEAE-cellulose and gel filtration by Sephadex G100. The two steps gave the specific activity of $155.8 \mathrm{U} / \mathrm{mg}$ protein, the purification fold was 4.15 and enzymatic yield was $64 \%$. The molecular weight of partial purified alginate lyase was $57 \mathrm{KDa}$. The results of antioxidant activity tests for different plants extracts utilizing DPPH radical scavenging activity were showed that the saad extract has high antioxidant activity $(71 \%)$ more than other plants extracts. While the results for inhibition experiment of alginate lyase were demonstrated that saad extract was the best inhibitor with inhibition ratio of 86 $\%$.
\end{abstract}

Keywords: Optimization, Molecular weight, Plant extracts, Inhibitors.

يونس

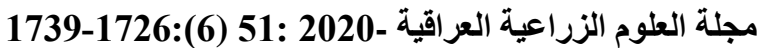

Pseudomonas aeruginosa NA11 انتاج , تنقية وتثبيط أنزيم الجنيت لاييز من العزلة المحلية

$$
\begin{aligned}
& \text { ريم وليب يونس } \\
& \text { مدرس } \\
& \text { * قسم التقتيات الأحيائية-كلية العلوم/ جامعة بغداد/ العراق }
\end{aligned}
$$

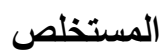

هدeudomonas aeruginosa هذفت هذه الدراسة إلى تحديد الظروف المثلى وتنقية انزيم الجينت لاييز من العزلة المحلية لبكتريا

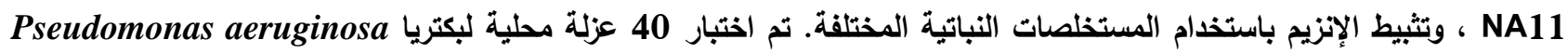
الممرضه لقدرتها على إنتاج انزيم الجينت لاييز. أظهرت العزلة المحلية لبكتريا P.aeruginosa NA11 الكفاعة العالية لانتاج انزيم الجينت لاييز مع فعالية نوعية 14,4 وحدة/ ملي غرام من البروتين. درست العديد من العوامل التي تؤثر على إنتاج الجينت لاييز من

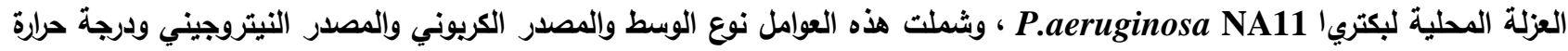

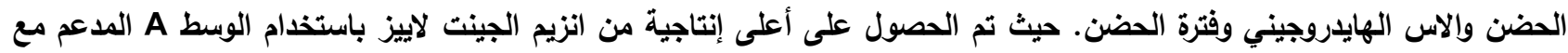
0,5 ٪ من الكلوكوز ونترات الصوديوم وعند الاس الهايدروجيني 7,5 بعد مدة حضن 24 ساعة وفي درجة حرارة 37 درجة مئوية. تم

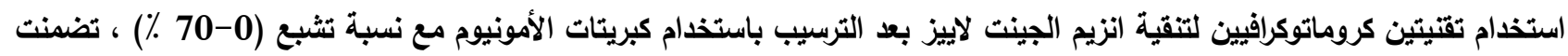
كروماتوكرافيا التبادل الأيوني باستخدام

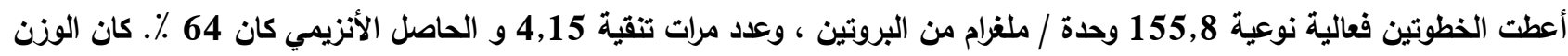

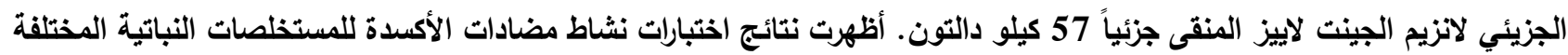

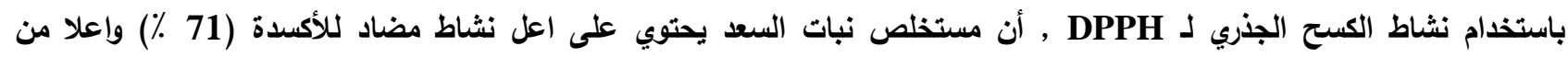

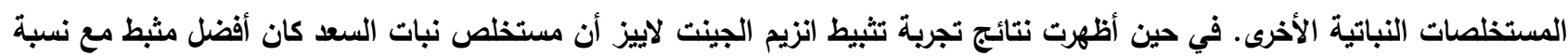

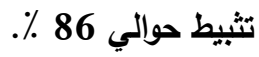
الكلمات المفتاحية: الظروف المثلى، الوزن الجزيئي، المستخلصات النباتية، المثبطات. 


\section{INTRODUCTION}

Alginate lyases are portrayed as either guluronate lyases (EC 4.2.2.11) or mannuronate (EC 4.2.2.3), catalyze of the alginate debasement, to a perplexing copolymer of $\mathrm{C} 5$ epimer beta-D-mannuronate and its alpha-Lguluronate. Alginate lyase is classified into seven polysaccharide lyase families by cleaving the polymer chain via a $\beta$-elimination mechanism, and organized based on primary structure. In nature alginate lyases can be secluded from a wide scope of organisms, including terrestrial bacteria, algae, some fungi, marine invertebrates and viruses. Bacterial alginates most generally belong to the families of polysaccharide lyase (PL). Alginate lyases can be secluded from a wide scope of organisms, including terrestrial bacteria, algae, some fungi, marine invertebrates and viruses. Alginate is polysaccharide in which $\beta$-Dmannuronate $(\mathrm{M})$ and alpha-L-guluronate $(\mathrm{G})$, are covalently (1-4)-connected in various arrangements. Alginate polysaccharide is principally used as a nourishment added substance to change of nourishment surface, because of its high thickness and gelling property (16). Alginate is a gelling polysaccharide founding great abundance as part of the cell wall and intracellular material in brown seawoods (phaeophyceae). Alginate has a widespread application due to its ability to form gels with calcium ions and to form a viscous solution (18). Also, it is widely used in the food, cosmetics, pharmaceuticals and for a biotechnological purpose like immobilization. The alginate from bacteria is profoundly acetylated in mannuronyl buildups and appears to play a significant role in the binding of P.aeuroginosa to target cells (15). Pseudomonas aeruginosa is encapsulated, Gramnegative bacillus that is found widespread in the environment and for $50 \%$ of airways patients in the hospitals. Pseudomonas aerugino$s a$ is an opportunistic pathogen, that causes illness infrequently in normal hosts, but is a master cause of contagion in patients with implied conditions. Pseudomonas aeruginosa is causing septicemia, cystic fibrosis (CF), infections of the respiratory tract, burn wounds, urinary tract, and blood. The opportunistic pathogen P.aeruginosa secretes of alginate as a capsule-like polysaccharide, that has an im- portant role in evasion of host defenses, especially during the chronic pulmonary disease of patients with cystic fibrosis (20). Researchers have shown that alginate lyase therapy (inhibition) can decrease viscosity in cultures of clinical isolates and in CF sputum; dissociates biofilms from abiotic surfaces and enhances the phagocytosis and manslaughter of P.aeruginosa by human immune cells, and also improves the efficacy of various antibiotics. The alginate lyase produced from P.aeruginosa plays an intriguing role in alginate production. Several other microbes such as Bacillus circulans and two species of marine Pseudomona spossess alginate lyase enzyme, which can be used as a source of carbon. Alginate lyase is also considered a subject of research for many years (17). The aim of current work was to determine the inhibitory effect of some plant extracts against the partial purified alginate lyase produced from local isolate of P.aeruginosa NA11.

\section{MATERIALS AND METHODS}

\section{Chemicals and media}

Brain Heart Infusion Broth (BHI), Sephadex G-100, DEAE-cellulose column, Coomassie brilliant blue and bovine serum albumin (BSA) were obtained from BDH, England. The plant extracts from the market in Baghdad-Iraq. Other chemicals were provided by Sigma Co. and BDH Chemicals.

\section{Bacterial isolates}

Forty local isolates of P.aeruginosa were taken from Biotechnology Department/College of Science /Baghdad University, Al-Yarmouk Hospital Baghdad, AL-Kadhimi HospitalBaghdad, includes seventeen were isolated from burns and twenty-three isolated from wounds. P.aeruginosa cells were activated at $37 \mathrm{C}^{\circ}$ in brain heart infusion broth.=

\section{Primary screening of alginate lyase- production}

The competency of forty P.aeruginosa local isolates for alginate lyase production were screened according to the method portray by Tavafi et al. (23). A $75 \mu 1$ of cell suspensions $\left(1.6 \times 10^{6}\right.$ cells $\left./ \mathrm{ml}\right)$ of all isolates were transferred into holes $(3 \mathrm{~mm})$ of the alginate agar medium containing of $0.5 \%$ sodium alginate, $1 \%$ peptone, $0.5 \%$ yeast extract, $0.5 \% \mathrm{NaCl}$, and $1.5 \%$ agar with $\mathrm{pH} 7.0$. After 48 hours of incubation time at $37{ }^{\circ} \mathrm{C}$, a clear zone ap- 
peared around each hole as a sign of alginate lyase production, the clearance zone ratios were measured, and the colony with the higher ratio was selected as the most effective isolate in alginate lyase production.

Secondary screening of alginate lyaseproduction (Quantitative screening)

The isolates which had particular clear zone hydrolysis in primary screening were chosen for its utilizing in secondary screening, which included creation of crude enzyme utilizing submerged fermentation in media consisting of $0.1 \%$ peptone, $0.5 \%$ sodium alginate , 0.5 $\%$ yeast extract $, 0.5 \% \mathrm{NaCl}, 0.1 \% \mathrm{MgSO}_{4}$, $0.1 \% \mathrm{KH}_{2} \mathrm{PO}_{4}$. A $50 \mathrm{ml}$ of production media was added in $250 \mathrm{ml}$ Erlenmeyer flasks then inoculated with $1.6 \times 10^{6}$ cells $/ \mathrm{ml}$ of local isolate of P.aeruginosa and incubation at $37{ }^{\circ} \mathrm{C}$ for $48 \mathrm{~h}$. The culture was centrifuged at 8000 (rpm) for 30 minutes. Protein concentration and alginate lyase activity were estimated.

Estimation activity and protein concentration of alginate lyase

The activity of alginate lyase was evaluated in solutions generated after enzyme extraction, via the method described by Miller (21), which depends on estimation of reducing sugar (by 3,5-Dinitrosalicylic acid, DNSA) as liberated from alginate after hydrolysis by alginate lyase (substrate concentration alginate $1 \%$ in phosphate buffer $\mathrm{pH}$ 7.0) to the reduced sugars formed by enzyme activity. The unit of enzyme activity is acquainted as the quantity of enzyme that release $1 \mu$ mole of glucose per minute in standard conditions. Protein concentration was estimated by the Bradford method (10).

\section{Optimization for alginate lyase production}

Many factors that influence on alginate lyase production from local isolate of P.aeruginosa had been studied, these factors included the type of media, carbon source, nitrogen source, initial $\mathrm{pH}$, the incubation temperature and period of incubation.

\section{Production media (type of substrate)}

Five different types of media were used for alginate lyase production from local isolate of P.aeruginosa NA11, including:- A: $0.5 \%$ sodium alginate, $0.1 \%$ peptone, $0.5 \%$ yeast extract, $0.5 \% \mathrm{Nacl}, 0.1 \% \mathrm{MgSO}_{4}, 0.1 \%$ $\mathrm{KH}_{2} \mathrm{PO}_{4}$; B: $0.5 \%$ Nacl, $1 \%$ ammonium sulphate, $0.5 \% \mathrm{KH}_{2} \mathrm{PO}_{4}, 1.5 \% \mathrm{~K}_{2} \mathrm{HPO}_{4}, 0.2 \%$
$\mathrm{MgSO}_{4}, 1 \%$ sodium alginate, $0.5 \%$ yeast extract; C: $0.1 \%$ peptone, $0.5 \%$ sodium alginate, $0.5 \%$ yeast extract ; D: $0.5 \%$ sodium alginate, $0.5 \%$ peptone, $0.1 \%$ yeast extract, $0.5 \% \mathrm{Nacl}, 0.1 \% \mathrm{MgSO}_{4}, 0.1 \% \mathrm{KH}_{2} \mathrm{PO}_{4}$; E: $1 \%$ peptone, $0.1 \%$ yeast extract, $3 \% \mathrm{Nacl}$, $0.5 \% \mathrm{KH}_{2} \mathrm{PO}_{4}, 1 \%$ ammonium sulphate, 0.5 $\%$ sodium alginate. Each media were inoculated with $1.6 \times 10^{6}$ cells $/ \mathrm{ml}$ of local isolate of P.aeruginosa NA11 and incubated at $37{ }^{0} \mathrm{C}$ for $48 \mathrm{~h}$.. Alginate lyase activity and protein concentration were estimated (23).

\section{Impact of carbon source}

Eleven various carbon sources were added to medium separately, and tested to set the better carbon source for alginate lyase production from local isolate of P.aeruginosa NA11; these sources include; glucose, fructose, galactose, lactose, maltose, carboxymethyl cellulose (CMC), sucrose, starch, mannitol, sodium benzoate and cellulose at concentration of 0.5 $\%$. Then incubated the cultures ( $\mathrm{pH} 7.0)$ at 37 ${ }^{\circ} \mathrm{C}$ for 48 hours (13). Alginate lyase activity and protein concentration were estimated.

\section{Nitrogen source}

Nitrogen sources were added to A media (containing glucose) separately, and tested to set the better source for alginate lyase production from local isolate of P.aeruginosa NA11, these sources were; $\mathrm{NaNO}_{3},\left(\mathrm{NH}_{4}\right)_{2} \mathrm{SO}_{4}$, $\mathrm{NH}_{3} \mathrm{NO}_{3}, \mathrm{NH}_{3} \mathrm{CL}$, urea, $\mathrm{Ca}(\mathrm{NO} 3), \mathrm{KNO}_{3}$, at $0.5 \%(\mathrm{w} / \mathrm{v})$. Then incubated the cultures $(\mathrm{pH}$ 7.0) at $37{ }^{\circ} \mathrm{C}$ for 48 hours (13). Alginate lyase activity and protein concentration were estimated.

\section{Optimum pH}

The A media (containing glucose and sodium nitrate) was hand out into many flasks, and adjusted of the $\mathrm{pH}$ to $4,4.5,5,5.5,6,6.5,7$, $7.5,8,8.5$ and 9, Each flask were inoculated with $1.6 \times 10^{6}$ cells $/ \mathrm{ml}$ of local isolate of P.aeruginosa NA11 and incubated at $37{ }^{\circ} \mathrm{C}$ for $48 \mathrm{~h}$. . Then the activity and protein concentration of alginate lyase were determined to the determination of the best $\mathrm{pH}(\mathbf{5})$.

\section{Incubation temperature}

The culture which comprise of the primary media contained on $\mathrm{NaNO} 3$ and glucose $(\mathrm{pH}$ 7.5) with $1.6 \times 10^{6}$ cells $/ \mathrm{ml}$ of local isolate of P.aeruginosa NA11, was incubated under various temperature degrees $(25,30,35,37,40$, 45 and 50$){ }^{\circ} \mathrm{C}$, to evaluate the ideal incubation 
temperature for production of enzyme. The concentration of protein and enzyme activity were determined $(\mathbf{8})$.

\section{Incubation period}

For determination of incubation period several flasks of the A media contained on $\mathrm{NaNO}_{3}$, glucose, and $\mathrm{pH} 7.5$ were inoculated with 1.6 $\times 10^{6}$ cells $/ \mathrm{ml}$ of local isolate of P.aeruginosa NA11. incubated of each flask at $37{ }^{\circ} \mathrm{C}$ and review or checked each 12 hours for three days. The activity of enzyme and protein concentration was estimated (5).

\section{Purification of alginate lyase}

Alginate lyase purification by ion-exchange chromatography: The first step for enzyme purification was precipitation by ammonium sulfate $(0-70 \%)$, then purification of alginate lyase by ion-exchange chromatography. The exchanger DEAE-cellulose was prepared as described by Whitaker (24). An amount of 12 $\mathrm{ml}$ of alginate lyase concentrated utilized sucrose was pushed through a DEAE-cellulose $(17 \times 3.0 \mathrm{~cm})$ column carefully using pasture pipette and washed with phosphate buffer (0.02 M, pH 7.0). After wash step end, the fractions eluted by phosphate buffer $\mathrm{pH} 7.0$ contain $\mathrm{NaCl}$ gradient (0.1-1 M), with flow rate of $30 \mathrm{ml} /$ hour, and collected of fractions at three $\mathrm{ml}$. Protein contents were moniterated with absorbency at $280 \mathrm{~nm}$, and the enzyme activity was estimated. The fractions which contained enzyme activity were collected and concentrated by sucrose.

\section{Alginate lyase purification by gel filtration chromatography}

Sephadex-G100 was readiness and packed following the instructions described by the manufacturing company (Pharmacia Sweden). Fourteen $\mathrm{ml}$ of the enzyme solution was passed carefully through the column $(57 \times 1.5 \mathrm{~cm})$ using a pasture pipette. The protein sample was eluted by $0.2 \mathrm{M}$ phosphate buffer $\mathrm{pH} 7.0$, and $3 \mathrm{ml}$ fractions were collected. The protein content of each fraction was determined spectrophotometrically at $280 \mathrm{~nm}$. The peaks were estimated by plotting the absorbency versus fraction number, and the enzyme activity was estimated for each fraction (7). The fractions which contained enzyme activity were collected and concentrated by sucrose.

Determination of molecular weight of partial purified alginate lyase by gel filtration chromatography: Sephadex-G100 column $(57 \times 1.5 \mathrm{~cm})$ was equilibrated for 24 hours with $0.2 \mathrm{M}$ (pH 7.0) phosphate buffer. The solution of blue dextran $2000(2 \mathrm{ml})$ was passed through the column and added of phosphate buffer ( $\mathrm{pH}$ 7.0) to the column. Two $\mathrm{ml}$ of partial purified alginate lyase (from purification step of alginate lyase by gel filtration chromatography) and standard proteins were passed through the column and eluted with phosphate buffer ( $\mathrm{pH}$ 7.0). Three $\mathrm{ml}$ of each parts were gathered with a flow rate of $36 \mathrm{ml} /$ hour and 3 $\mathrm{ml}$ for each fraction. The O.D. (600 nm) was estimated for blue dextran 2000, and the void volume (Vo) was estimated of the column. Additionally, evaluated of the elution volume for alginate lyase and standard proteins (Aldolase, Urease, Trypsin, and Bovine serum albumin) (1).

\section{Anti-Oxidant activity experiment for plant extracts}

All the plant extracts (from the market in Baghdad-Iraq) were estimated for the antioxidant activity utilized 1,1-diphenyl-2-picrylhydrazyl (DPPH) depending to the method described by Shen et.al., (22). The DPPH solution $(0.1 \mathrm{mM})$ was prepared in methanol and one $\mathrm{ml}$ of this solution was added to three $\mathrm{ml}$ of the solution of all extracts in methanol (at $100 \mu \mathrm{g} / \mathrm{ml}$ concentration), these extracts are including Blackseed, Mint, Linseed, Soybean, Rose, Fenugreek, Glycerin, Ginger, Aloe, Avocado, Clove, Sesame, Ant, Saad, Mustard, Argan, Garlic, Cress, Tea tree and Bitter Almond extract. The mixtures were shaken strongly and remaining for 30 minutes at room temperature without light. The absorbance for each examine was estimated at $517 \mathrm{~nm}$ via an UV-VIS spectrophotometer. Ascorbic corrosive was utilized as a kind of perspective. Lower absorbance estimations of response blend signalize higher free radical scavenging activity. The ability of scavenging the DPPH radical was determined by utilizing the accompanying recipe:

Effect of DPPH scavenging (\% inhibition $)=$ [(A0-A1)/A0]*100)

Whereas A0 is the control reaction absorbance, and $\mathrm{A} 1$ is the absorbance in the presence of all of the extract samples and reference. All the tests were performed in duplicates and the results were averaged. 
Effects of the many plant extracts on partial purified alginate lyase activity

The impact of (inhibitors) plant extracts on alginate lyase activity were inspected via using several types of plant extracts (from the market) at a ratio $(1: 1 \mathrm{v}: \mathrm{v})$. These extracts are including Blackseed, Mint, Linseed, Soybean, Rose, Fenugreek, Glycerin, Ginger, Aloe, Avocado, Clove, Sesame, Ant, Saadl, Mustard, Argan, Garlic, Cress, Tea tree and Bitter Almond extract. The enzyme was separately incubated with each plant extracts for $30 \mathrm{~min}$ at $37^{\circ} \mathrm{C}$, individually. The enzyme (control) and inhibited enzyme were estimated and the enzyme activity without additives was defined as $100 \%$. Then calculate the percent of inhibition according to equation $(\mathbf{6})$ :

Inhibition $\%=[($ Enzyme activity $\mathrm{U} / \mathrm{ml})-$ (Enzyme activity U/ml + Inhibitor) / (Enzyme activity $\mathrm{U} / \mathrm{ml})] \mathrm{X} 100$.

Table 1. Primary and secondary screening of local isolates P.aeruginosa for alginate lyase production

\begin{tabular}{|c|c|c|c|c|c|}
\hline \multirow{2}{*}{$\begin{array}{c}\text { Local isolates of } \\
\text { P.aeruginosa }\end{array}$} & \multirow{2}{*}{$\begin{array}{l}\text { Sources } \\
\text { of isolates }\end{array}$} & \multirow{2}{*}{$\begin{array}{l}\text { Primary screening } \\
\text { The ratio of zone } \\
\text { Hydrolysis (mm) }\end{array}$} & \multicolumn{3}{|c|}{ Secondary screening } \\
\hline & & & $\begin{array}{c}\text { Activity } \\
\text { U/ml }\end{array}$ & $\begin{array}{c}\text { Protein con- } \\
\text { centration } \\
\mathrm{mg} / \mathrm{ml}\end{array}$ & $\begin{array}{l}\text { Specific activi- } \\
\text { ty U/mg }\end{array}$ \\
\hline P.aeruginosa NA4 & Wounds & 23.0 & 0.124 & 0.026 & 4.77 \\
\hline P.aeruginosa NA8 & Burns & 23.3 & 0.14 & 0.036 & 3.89 \\
\hline P.aeruginosa NA16 & Wounds & 23.9 & 0.16 & 0.012 & 13.33 \\
\hline P.aeruginosa NA22 & Burns & 23.2 & 0.13 & 0.036 & 3.6 \\
\hline P.aeruginosa NA11 & Burns & 24.7 & 0.245 & 0.017 & 14.4 \\
\hline P.aeruginosa NA27 & Wounds & 23.6 & 0.147 & 0.019 & 6.39 \\
\hline P.aeruginosa NA36 & Wounds & 23.0 & 0.105 & 0.023 & 4.56 \\
\hline
\end{tabular}

\section{Optimization for alginate lyase production}

Substrate type: Five kinds of substrate were examined for their efficiency of alginate lyase production. The results in figure (1) demonstrated that the highest alginate lyase yield was

\section{Results and Discussions}

Primary and secondary screening of local isolates P.aeruginosa for alginate lyase production

Forty local isolates of P.aeruginosa were primary examined for production of alginate lyase utilizing alginate agar media. The isolates efficiency were measured primarily depending on appearance of clear zone on agar media around growth culture. The results in primary screening show that seven local isolates were more efficiency for enzyme production, then these isolates selected for secondary screening (Table 1). The local isolates of P.aeruginosa NA11 was the better local isolate for alginate lyase production with higher specific activity (14.4 U/mg). observed by A media with alginate lyase specific activity was $14.56 \mathrm{U} / \mathrm{mg}$. While the lower production was in employed $\mathrm{D}$ medium with $8.6 \mathrm{U} / \mathrm{mg}$. 


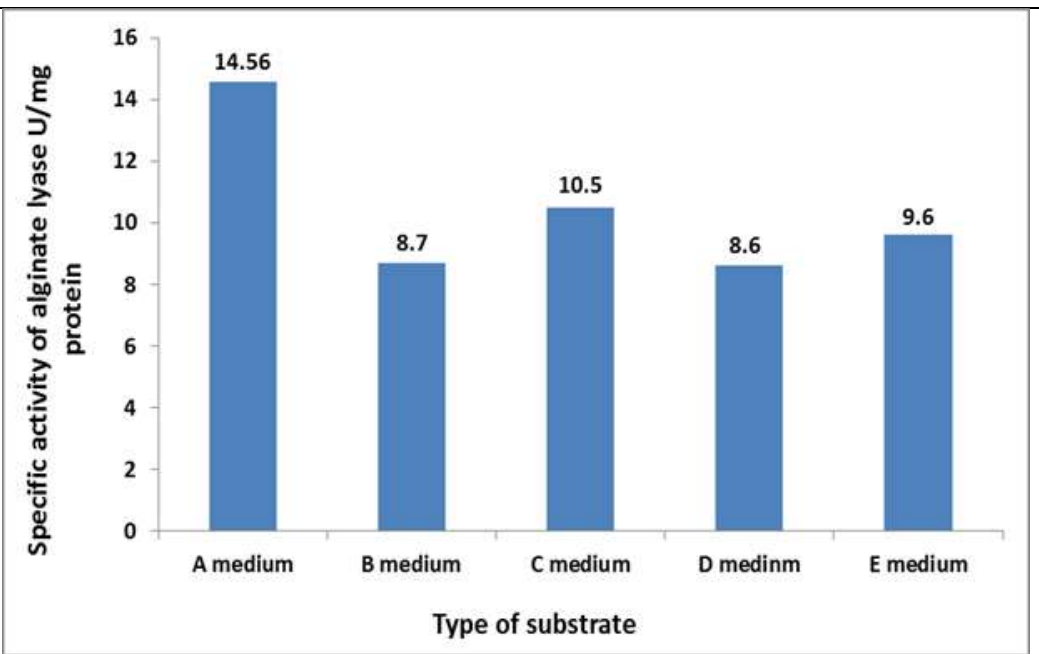

Figure 1. The impact of substrate type on alginate lyase production from P.aeruginosa NA11, incubation for $48 \mathrm{~h}$. at $37^{\circ} \mathrm{C}$ and $\mathrm{pH}$ 7.0

El-Sanshoury et al. (14), who found that the medium composed from $30 \mathrm{~g} / \mathrm{l}$ sucrose, $1 \mathrm{~g} / \mathrm{l}$ KH2PO4, $0.1 \mathrm{~g} / 1 \mathrm{NaNO} 3,0.5 \mathrm{~g} / \mathrm{l} \mathrm{NaCl}, 0.01$ $\mathrm{g} / \mathrm{l} \mathrm{FeSO} 4,0.01 \mathrm{~g} / \mathrm{l} \mathrm{MgSO} 4,0.001 \mathrm{~g} / \mathrm{l} \mathrm{Na}-$ $\mathrm{MoO} 4,8.5 \mathrm{~g} / \mathrm{l}$ alginate and $0.06 \mathrm{~g} / \mathrm{l} \mathrm{CaCl}$, was the best medium for alginate lyase production by Azotobacter vinelandii isolate in submerged fermentation. Commercial success of a fermentation process depends a lot on continuous productivity improvement by strain improvement programs and in turn the effectiveness of any strain improvement system depends on successful screening techniques. The substrate which provides all the necessary nutrients to the microorganisms which grow in it should be considered as the ideal substrate. However, some of the nutrients in the sub- strates may be available in suboptimal concentrations, or even absent. In such cases, external supplementation with these would become necessary.

\section{Impact of additional carbon source}

various carbon sources were efficiency examined for production of alginate lyase. These sources including glucose, fructose, galactose, lactose, maltose, Carboxymethyl cellulose (CMC), sucrose, starch, mannitol, sodium benzoate, and cellulose at $0.5 \%(\mathrm{w} / \mathrm{v})$. The results demonstrated that the best carbon source for alginate lyase production from local isolate of P.aeruginosa NA11 was glucose at a highest specific activity of $17.33 \mathrm{U} / \mathrm{mg}$, while other carbon sources showed lower specific activities (Figure 2).

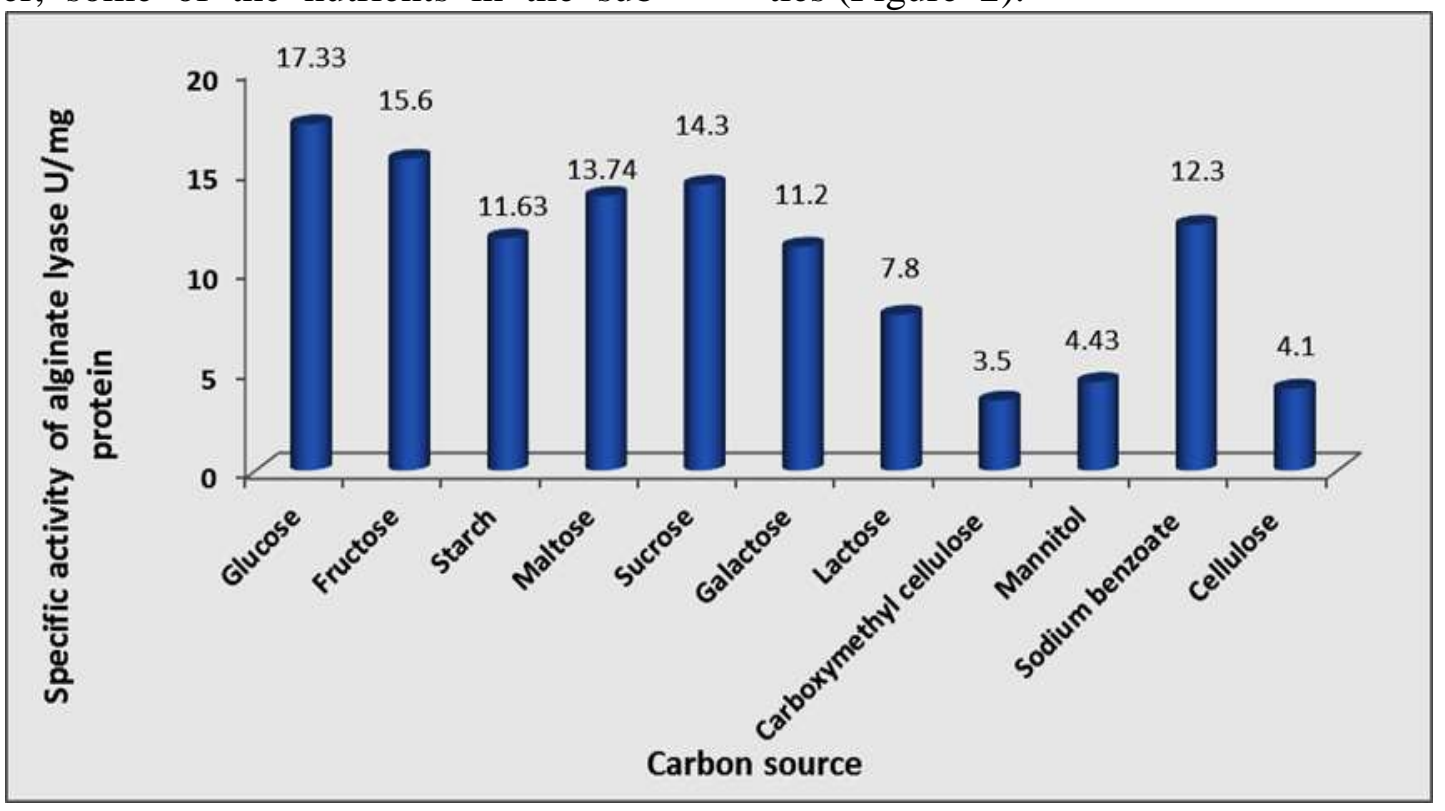

Figure 2. The impact of carbon sources on alginate lyase production from local isolate of P.aeruginosa NA11, utilizing A media (pH 7.0), incubation for $48 \mathrm{~h}$. at $37^{\circ} \mathrm{C}$ 
The carbon source is the most significant factor in the production of alginate lyase, and it has an influence on the synthesis of alginate lyase by adding the appropriate amount of other sugar to the culture media. In the production of bacterial alginate lyase, the effect of carbon source on the production of enzymes was reported, and glucose showed the highest potential for the production of laccase because glucose is monosaccharide, which is easily broken down and quickly used by the microorganism. Thus, in the following studies, glucose was used as the sole source of carbon (2). AlJumaily and Ali (4), found that the maximum yield of alginate lyase from Bacillus circulans was achieved when the alginate utilized as the carbon source in submerged fermentation with $112.75 \mathrm{U} / \mathrm{mg}$.

\section{Impact of nitrogen source}

Various of nitrogen sources were utilized to efficiency examined to increase of alginate lyase production. The highest yield of enzyme was shown in sodium nitrate as a nitrogen source, that gave $(20.4 \mathrm{U} / \mathrm{mg})$ specific activity, while $\left(\mathrm{NH}_{4}\right)_{2} \mathrm{SO}_{4}, \mathrm{NH}_{3} \mathrm{NO}_{3}, \mathrm{NH}_{3} \mathrm{CL}$, urea, $\mathrm{Ca}(\mathrm{NO} 3)$ and $\mathrm{KNO}_{3}$ showed low specific activities. This indicates that sodium nitrate $\left(\mathrm{NaNO}_{3}\right)$ is the most efficiency nitrogen source for alginate lyase production from local isolate of P.aeruginosa NA11 (Figure -3).

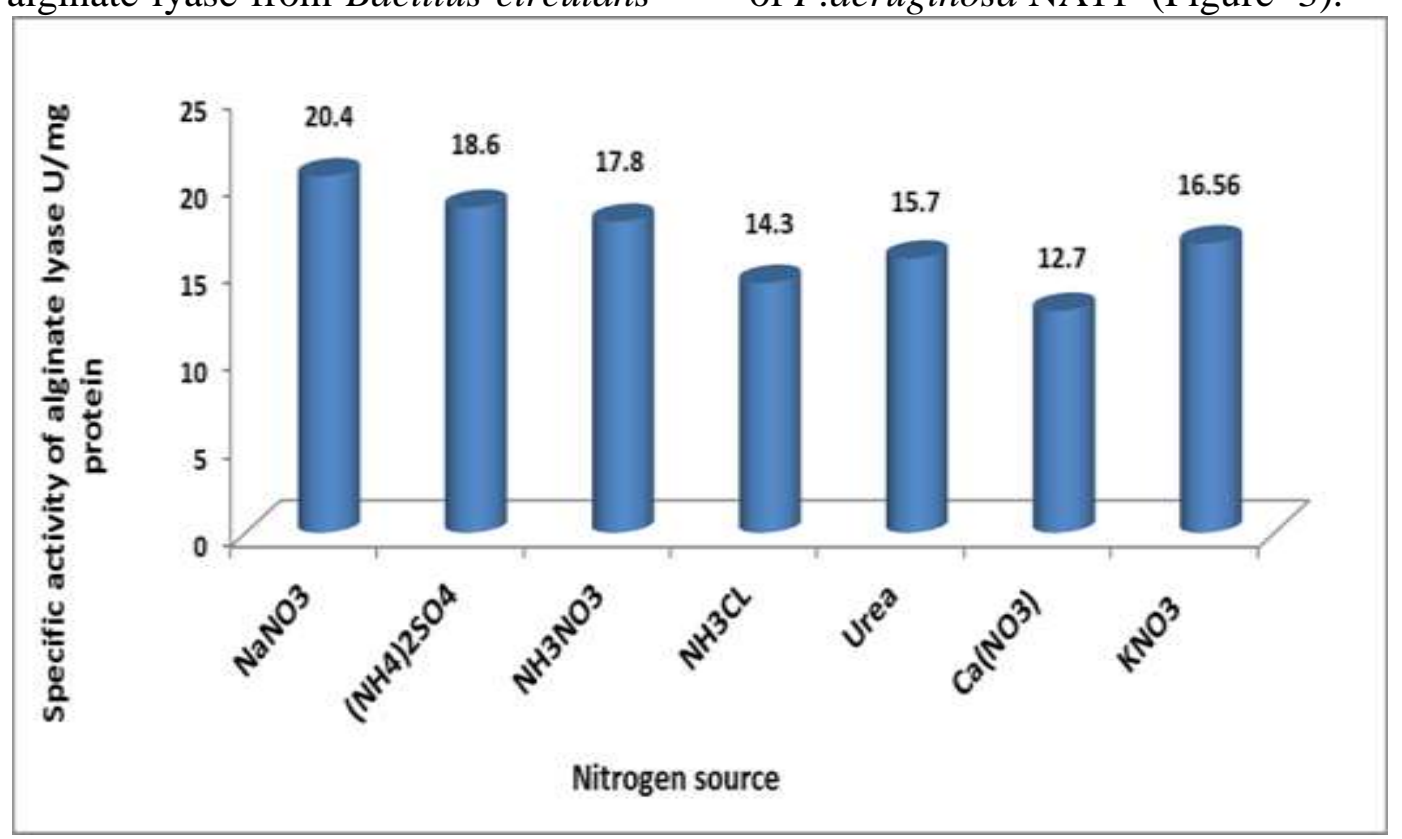

Figure 3. The impact of nitrogen sources on alginate lyase production from local isolate of P.aeruginosa NA11, employing the A media (pH 7.0) supplemented with glucose and incubation for $48 \mathrm{~h}$. at $37^{\circ} \mathrm{C}$

Nitrogen source plays a significant role in the production of many of enzyme (19), like alginate lyase. The nature and concentration of nitrogen is essential for the production of alginate lyase in the culture medium to grow the organism. Medium with sodium nitrate exhibited the highest activity of alginate lyase. Sodium nitrate is the simplified source of nitrogen sources, and the microorganism can be readily absorbed. Al-Jumaily and Ali (4), found that the best nitrogen source for alginate lyase production was peptone by using submerged fermentation, with specific activity
$275 \mathrm{U} / \mathrm{mg}$. Also Kotil et al. (20), who showed that the better nitrogen source for alginate lyase production from Pseudomonas aeruginosa AG LSL-11, was ammonium nitrate.

\section{Optimum pH of production media}

The optimum $\mathrm{pH}$ for alginate lyase production was determined after the cultures incubation. The results in figure (4) demonstrated that the better $\mathrm{pH}$ for alginate lyase production was 7.5 with $23.2 \mathrm{U} / \mathrm{mg}$. Kotil et al. (20), who demonstrated that the best $\mathrm{pH}$ for alginate lyase production by Pseudomonas aeruginosa AG LSL11 was 8.5. 


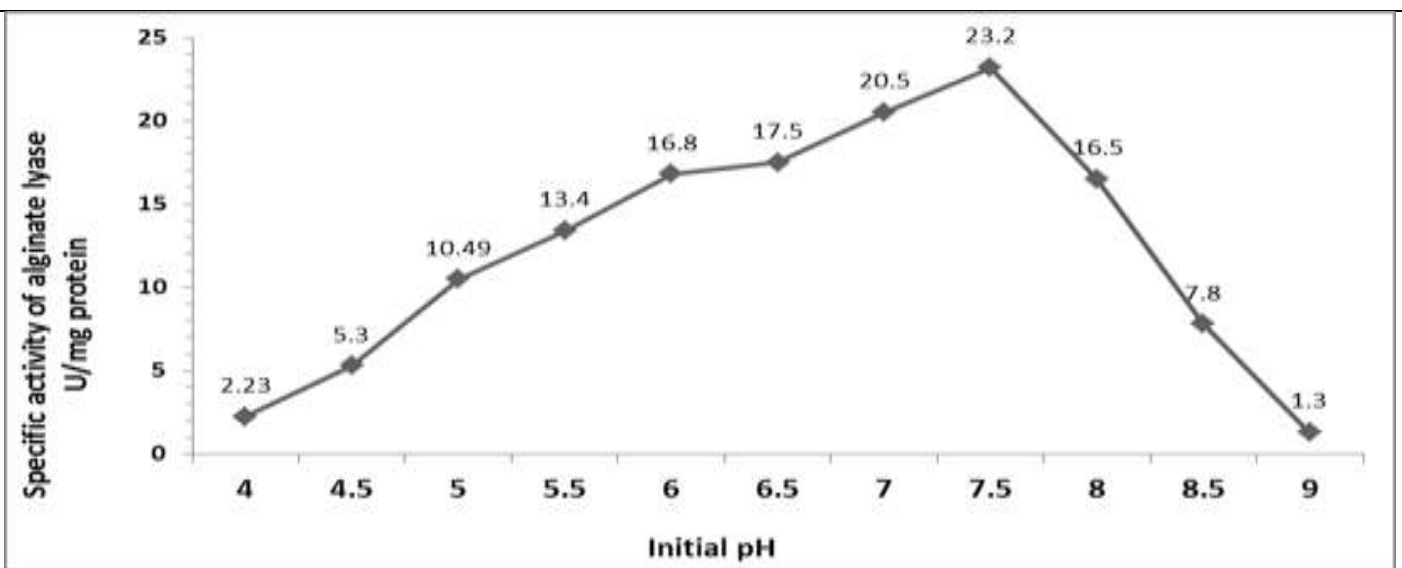

Figure 4. The impact of $\mathrm{pH}$ on production of alginate lyase by local isolate of P.aeruginosa NA11, utilizing the A media (supplemented with glucose and sodium nitrate) and incubation for $48 \mathrm{~h}$. at $37^{\circ} \mathrm{C}$

The $\mathrm{pH}$ impacts in protein generation on account of its job in the dissolvability of medium substrates and its impact on the ionization of the substrate and its accessibility for the bacterial development, in addition the $\mathrm{pH}$ influences the efficiency and compound solidness. The $\mathrm{pH}$ impacts on enzyme yield due to its significant role in the substrates solubility, impact on the substrate ionization and its accessibility for the growth of bacteria, in addition the $\mathrm{pH}$ influences enzyme stability and the efficiency (3).

\section{Incubation temperature}

So as to scrutinize the role of temperature on alginate lyase production, diverse temperature was utilized comprise of $25,30,35,37,40,45$ and $50^{\circ} \mathrm{C}$. The outcomes in figure (5) demonstrated that the ideal incubation temperature was $37{ }^{\circ} \mathrm{C}$, which gave $23.3 \mathrm{U} / \mathrm{mg}$. While the other temperatures show low enzyme yield. Higher and lower temperatures compared with the better temperature seem falling in the values of specific activities. Lower temperature diminishes the specific activity due to its unsatisfactory for bacterial development, accordingly, it bringing down the enzyme yield. The higher temperature lead to limiting media water content by vaporization, subsequently, it impact on cells development, in addition higher temperature confines oxygen concentration. Past examinations discovered it is pointless the congruity between the ideal temperature for microorganism development and the ideal temperature for activity of enzyme (5). Kotil et al. (20) found that the better temperature for alginate lyase generation from Pseudomonas aeruginosa AG LSL-11 was $30^{\circ} \mathrm{C}$, with activity $0.355 \mathrm{U} / \mathrm{ml}$.

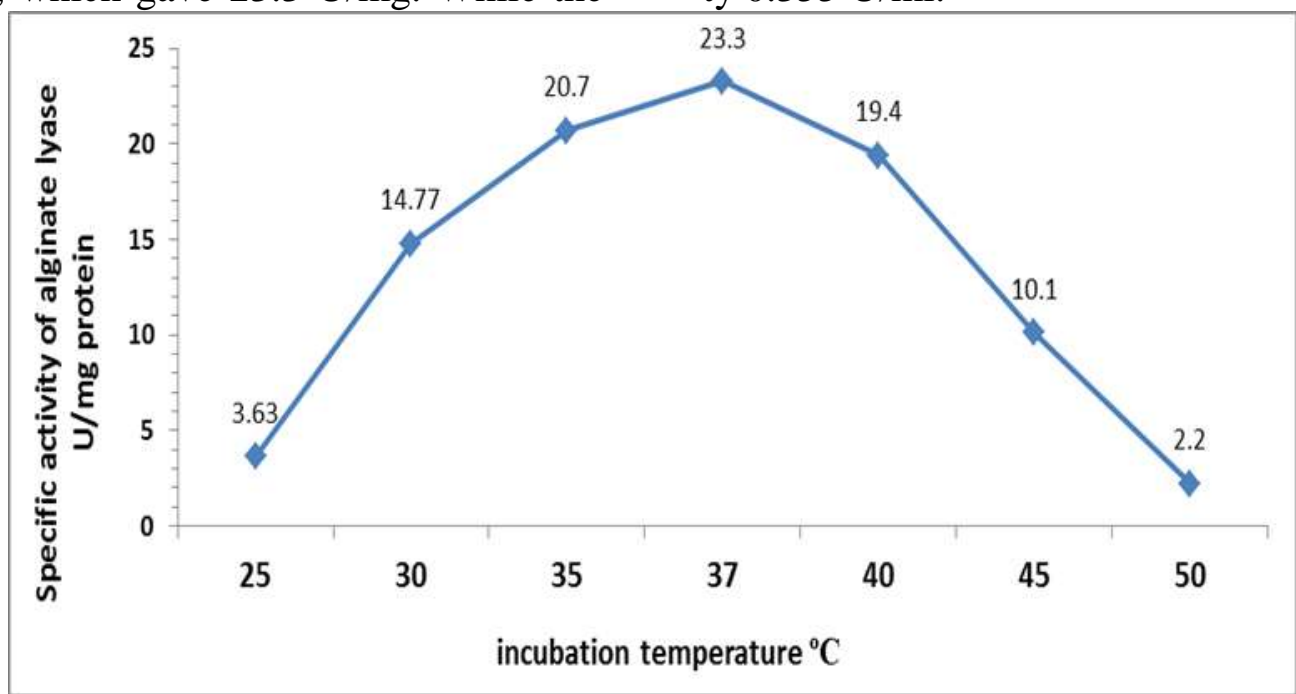

Figure 5. The impact of incubation temperature on production of alginate lyase from local isolate of P.aeruginosa NA11, using the A media supplemented with glucose, sodium nitrate, pH 7.5 and incubation for $48 \mathrm{~h}$ 


\section{Incubation duration}

The outcomes in figure (6) demonstrated that the impact of incubation duration on alginate lyase production by local isolate of P.aeruginosa NA11, which checked every 12 hours for three days. The elevated specific activity $(37.4 \mathrm{U} / \mathrm{mg})$, was at 24 hours of incubation. Tavafi et.al.(23), found that the best time for the production of alginate lyase from $\mathrm{Ba}$ cillus sp. was 12 hours.

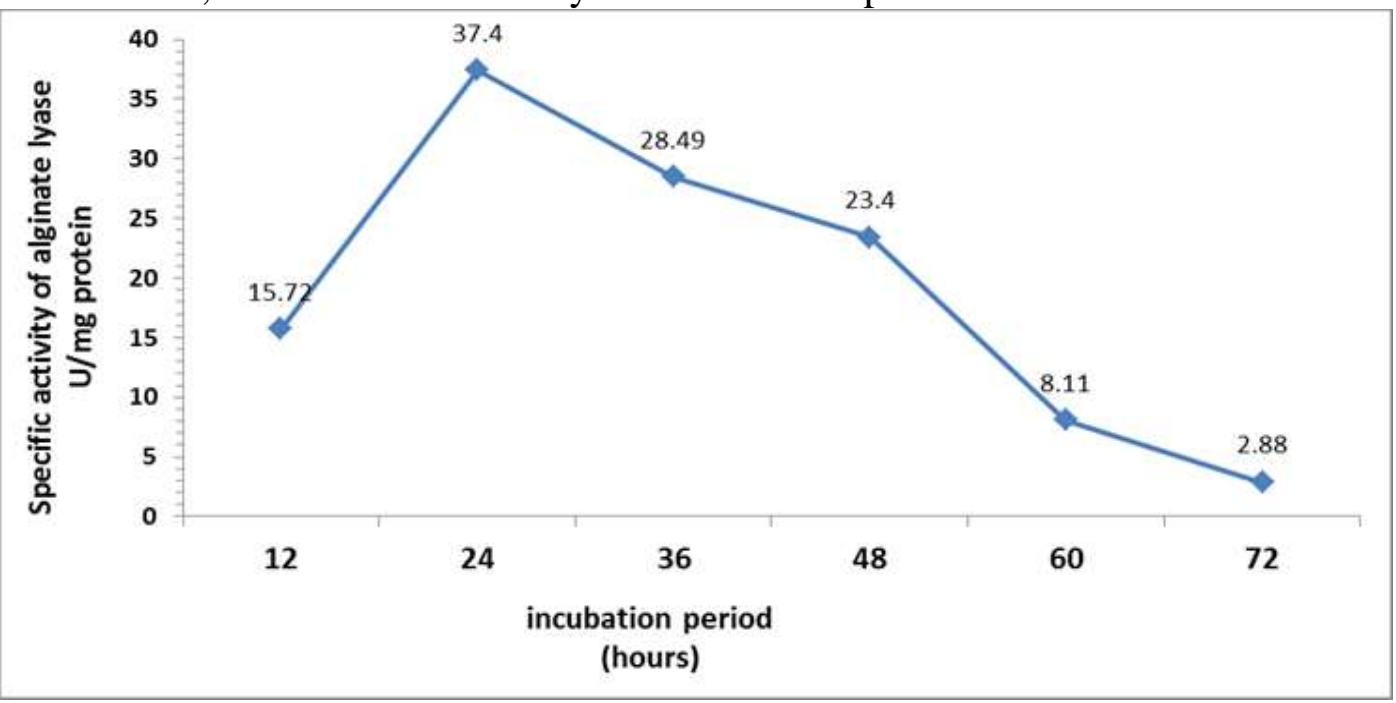

Figure 6. The impact of incubation period on alginate lyase production from local isolate of P.aeruginosa NA11, employing A media (pH 7.5) supplemented with glucose, sodium nitrate, and incubation at $37^{\circ} \mathrm{C}$.

The alginate lyase generation diminishes following 24 hours of incubation duration it might be alluded to the creation of decreasing sugar in culture media which lead to restraint of alginate lyase creation due to these sugars are more facilely carbon source than alginate, notwithstanding exhaustion of the supplements in the medium. As well as the reason may be referred to that the enzyme may digestion by protease enzyme which is produced from the same of isolate (10).

\section{Purification of alginate lyase}

\section{Ion exchange chromatography}

Ion exchange chromatography of crude enzyme was done after precipitation using ammonium sulphate with saturation ratio of $0-70$ $\%$, then dialysis with phosphate buffer $0.02 \mathrm{M}$, pH 7.0, and concentration by sucrose, DEAEcellulose used as ion exchanger in presence of phosphate buffer $0.02 \mathrm{M}, \mathrm{pH}$ 7.0. The results showed the appearance of two peaks which represented by fractions 12-20, 22-24 after wash step as shown in figure (7). Addition of phosphate buffer with $\mathrm{NaCl}$ gradients (elution step) allows five peaks to be obtained and represented by fraction 34-49, 50-56, 57-67,6873,74-76. Each fraction was tested for alginate lyase activity. In the elution step, the fractions 37-51 were showed enzyme activity. Also, the result indicates that alginate lyase produced from local isolate of P.aeruginosa NA11 carried negative charges that attracting with positive charge of DEAE-cellulose therefor alginate lyase enzyme was eluted and goes to elution step. The results of enzyme purification after fractions collected and concentrated by sucrose show that the enzyme activity was $5.21 \mathrm{U} / \mathrm{ml}$, specific activity of $140.73 \mathrm{U} / \mathrm{mg}$, the protein concentration of $0.037 \mathrm{mg} / \mathrm{ml}$, a purification fold of 3.7 and yield of $72 \%$ were obtained (table 2). 


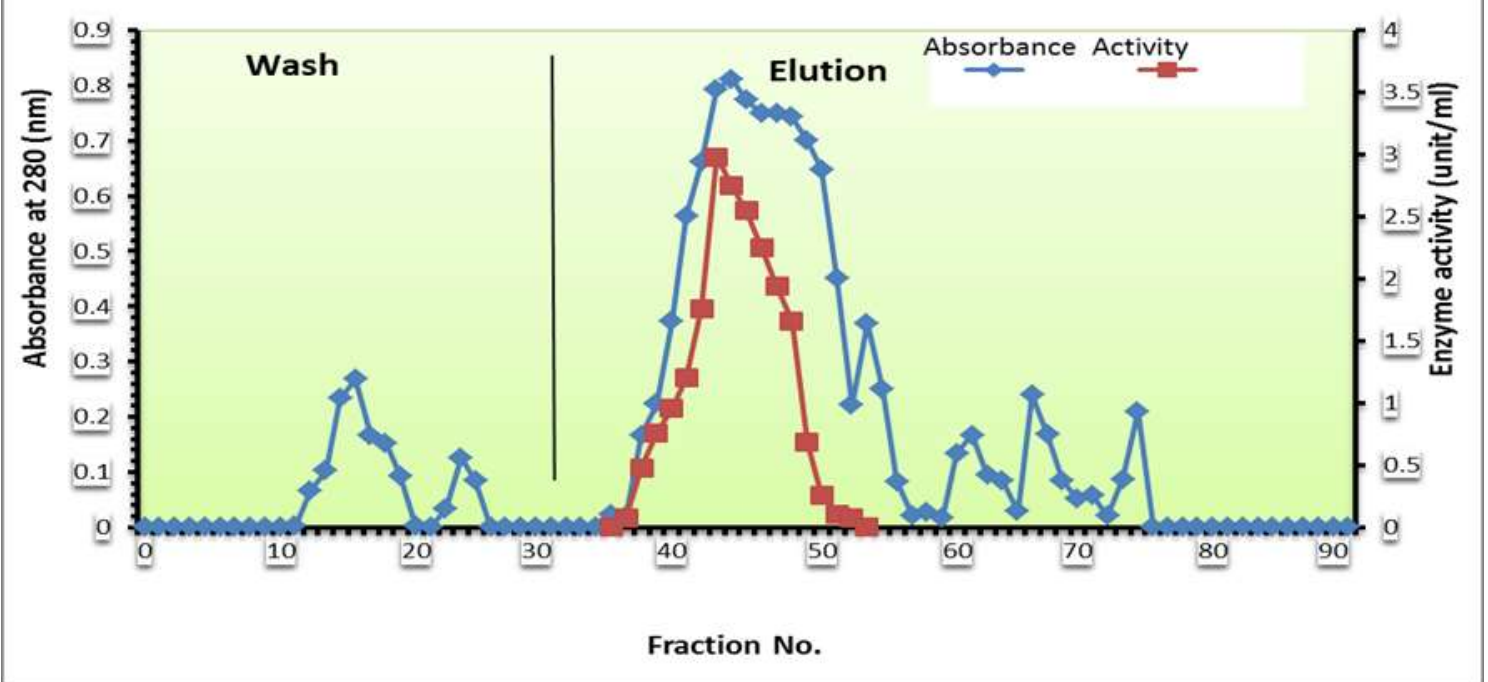

Figure 7. Purification of alginate lyase from local isolate of P.aeruginosa NA11 by ion exchange chromatography utilizing DEAE-cellulose column $(17 \times 3.0 \mathrm{~cm})$ equilibrated with phosphate buffer $(0.02 \mathrm{M}, \mathrm{pH}$ 7.0), and eluted with a phosphate buffer contain $\mathrm{NaCl}$ gradient $(0-1 \mathrm{M})$ in flow rate $30 \mathrm{ml} / \mathrm{hr} ., 3 \mathrm{ml}$ for each fraction

Ion exchange chromatography utilized in many studies of alginate lyase purification from bacteria, Beltagy et.al., (9) utilized DEAE-cellulose in alginate lyase purification from Pseudomonas stutzeri MSEA04 with specific activity $105 \mathrm{U} / \mathrm{mg}$ and yield $79.4 \%$. Davidson et al. (12) used DEAE-cellulose and CM-Sephadex column for alginate lyase purification from marine bacterium with purification fold was $15.3,120.0$, specific activity 9.2 , $73.0 \mathrm{U} / \mathrm{mg}$, and the yield $47,10 \%$, respectively.

Gel filtration chromatography
Gel filtration step followed ion exchange, and this step was done using Sephadex G-100 gel. The results in figure (8) of the enzyme purification by gel filtration, shows three peaks of protein were separated. After estimating the enzymatic activity of each peak, only one shows activity in fractions 34-48, the fractions which show activity are collected then mixed together and the volume was concentrated by sucrose. This step of gel filtration gives the specific activity of $155.8 \mathrm{U} \backslash \mathrm{mg}$, purification fold 4.15 and enzymatic yield $64 \%$ (table 2).

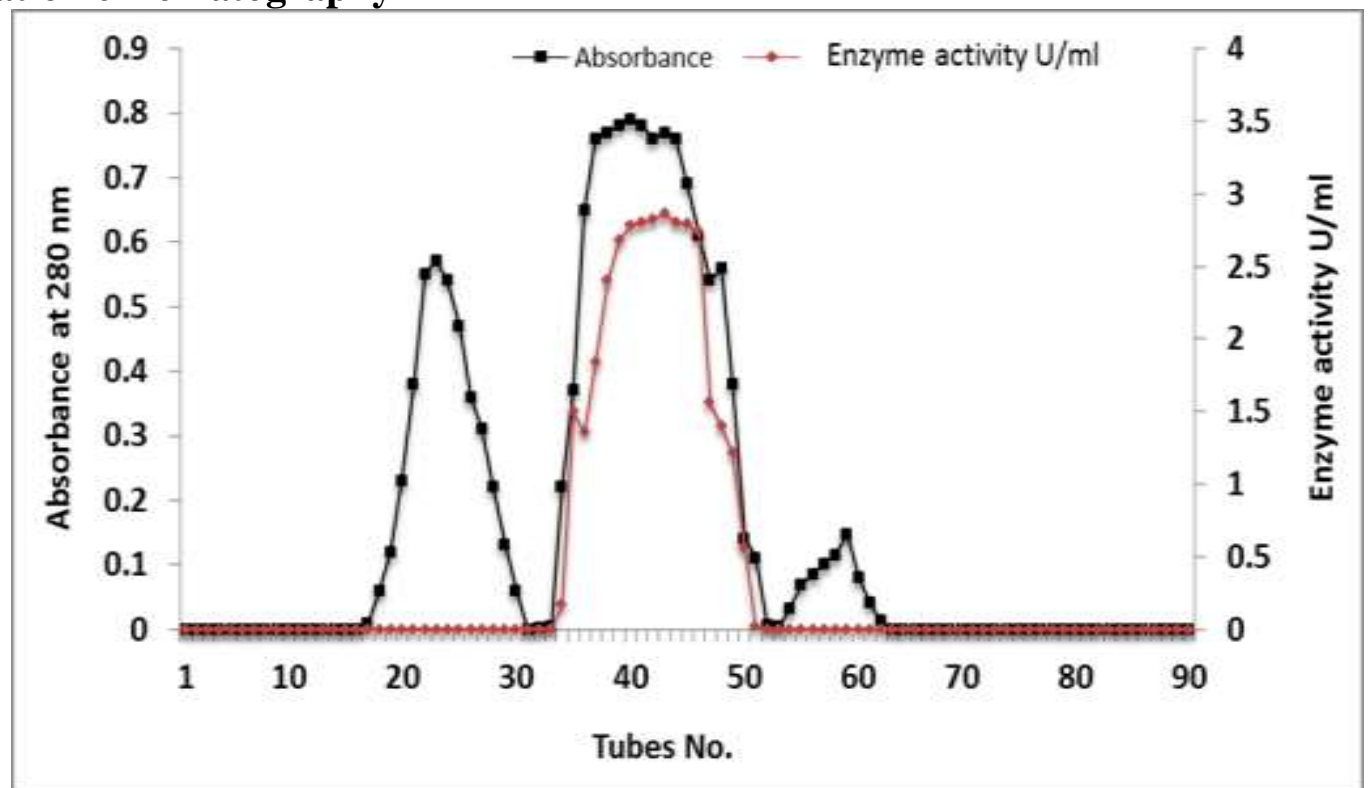

Figure 8. Partial purification of alginate lyase from local isolate of P.aeruginosa NA11 by gel filtration chromatography utilizing Sephadex G-100 column $(57 \times 1.5 \mathrm{~cm})$ equilibrated with 0.2 $M$ phosphate buffer $\mathrm{pH} 7.0$ in a flow rate of $36 \mathrm{ml} / \mathrm{hour}$, and $3 \mathrm{ml}$ for each fraction 
Davidson et al. (12) used sephadex G-100 for alginate lyase purification from marine bacterium with purification fold was 92.0 , specific activity $55.0 \mathrm{U} / \mathrm{mg}$, and the yield $23 \%$. While
Beltagy et al. (9), utilized sephadex G-100 in alginate lyase purification from Pseudomonas stutzeri MSEA04 with specific activity 116 $\mathrm{U} / \mathrm{mg} \mathrm{U} / \mathrm{mg}$ and yield $48.2 \%$.

Table 2. Purification steps of alginate lyase produced from local isolate of P.aeruginosa NA11

\begin{tabular}{|c|c|c|c|c|c|c|c|}
\hline Purification steps & $\begin{array}{c}\text { Volume } \\
(\mathrm{ml})\end{array}$ & $\begin{array}{c}\text { Activity } \\
\text { (U/ml) }\end{array}$ & $\begin{array}{c}\text { Protein } \\
\text { concentration } \\
(\mathrm{mg} / \mathrm{ml}) \\
\end{array}$ & $\begin{array}{l}\text { Specific } \\
\text { activity } \\
\text { (U/mg) }\end{array}$ & $\begin{array}{c}\text { Total } \\
\text { activity }\end{array}$ & $\begin{array}{l}\text { Purification } \\
\quad \text { fold }\end{array}$ & $\begin{array}{l}\text { Yield } \\
(\%)\end{array}$ \\
\hline $\begin{array}{c}\text { Crude extracted } \\
\text { enzyme } \\
\text { Saturated ammonium } \\
\text { sulfate }(0-70 \%)\end{array}$ & 50 & 2.03 & 0.054 & 37.5 & 101.25 & 1 & 100 \\
\hline $\begin{array}{l}\text { Ion-exchange DEAE- } \\
\text { cellulose column }\end{array}$ & 12 & 7.34 & 0.125 & 58.73 & 88.08 & 1.5 & 87 \\
\hline $\begin{array}{l}\text { (after concentration } \\
\text { by dialysis tube } \\
\text { utilizing sucrose) } \\
\text { Gel filtration chro- } \\
\text { matography column } \\
\text { (after concentration } \\
\text { by dialysis tube } \\
\text { utilizing sucrose) }\end{array}$ & 14 & 4.05 & 0.026 & 140.73 & 72.94 & 4.15 & 72 \\
\hline
\end{tabular}

Molecular weight determination of alginate lyase:Gel filtration chromatography was used to estimate alginate lyase molecular weight, according to the standard curve, which elucidate the relationship between the molecular weight Log of standard proteins versus VelVo as clarify in (Figure 9), which display that the molecular weight of partial purified alginate lyase from local isolate of P.aeruginosa NA11 was 57 kilo Dalton. Ghadam et.al., (17) found that the molecular weights of alginate lyase from P.aeruginosa were 60000 daltons. Another study by Zhua et al. (25) exhibit that the molecular weights of partial purified alginate lyase by Microbulbifer spp. was 26 K.D.

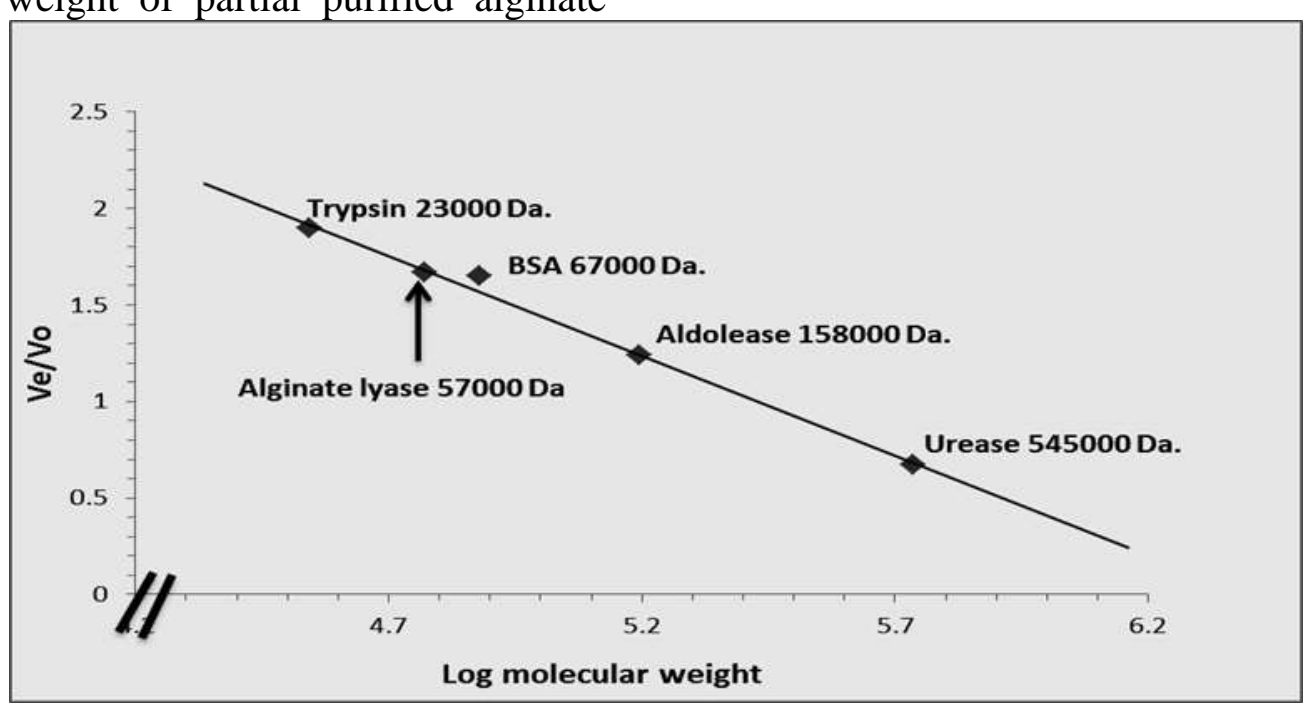

Figure 9. Estimation of the molecular weight for partial purified alginate lyase from local isolate of P.aeruginosa NA11 by gel filtration chromatography.

Anti-Oxidant activity assay of plant extracts DPPH radical scavenging activity was used to detection on antioxidant activity for different types of plants extracts, which used for inhibition of partial purified alginate lyase produced from local isolate of P.aeruginosa NA11. The results in figure (10) show that the saad extract has the antioxidant activity $(71 \%)$ more than other plants extracts. Reactive oxidative substrate produced as by-product plays significant role in the signaling of the cell. Where, biomolecule oxidation produced immoderate re- 
active oxygen species which caused main damage to cell structure and resulted in several kinds of diseases such as stroke, diabetes, and cancer. Antioxidants are important key inhibitors in the protection and also as a defense mechanism

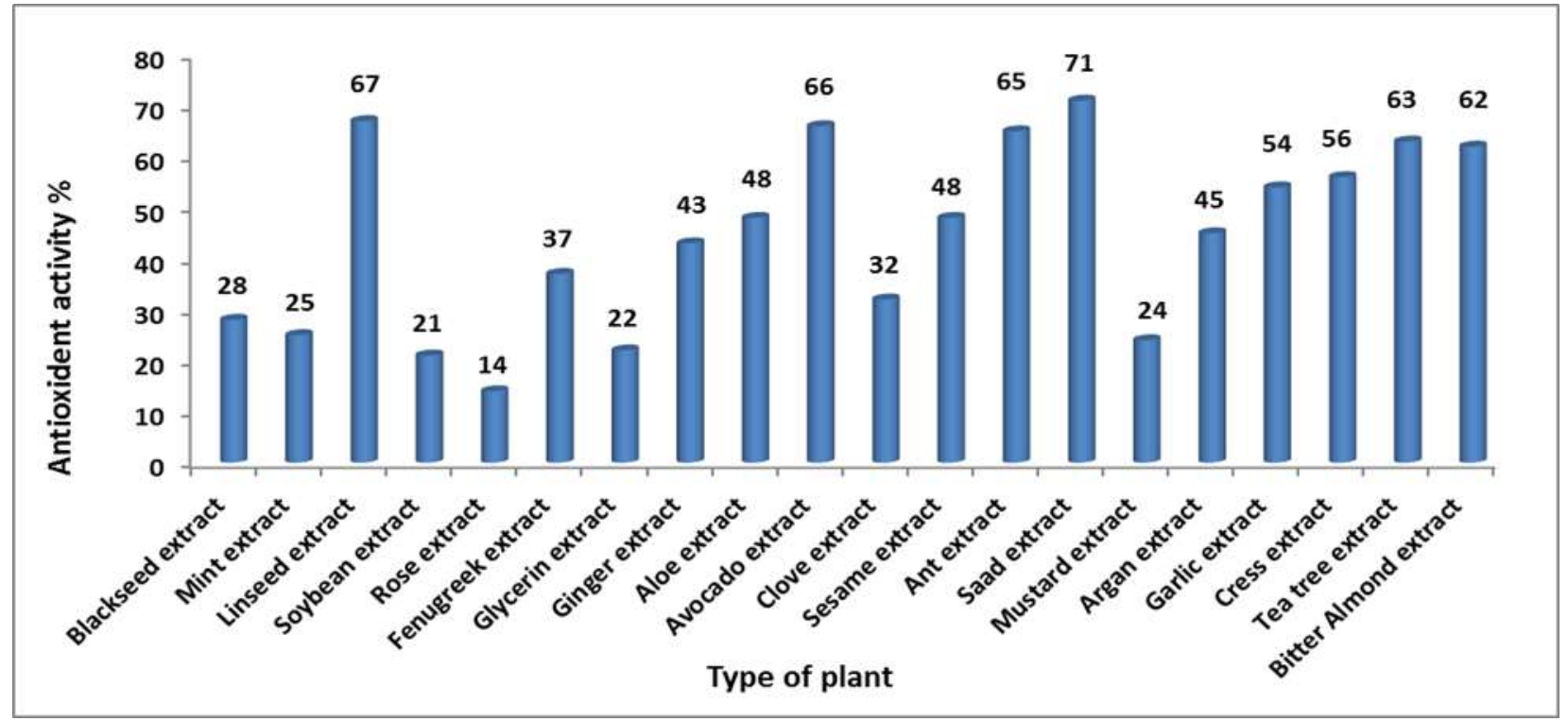

Figure 10. Representation of antioxidant activity for different plants

Effects of the plant extracts on alginate lyase activity as inhibitors

The impact of inhibitors (plant extracts) on alginate lyase activity were scrutinized by using different types of plant extracts at a ratio $1: 1(\mathrm{v}: \mathrm{v})$. In this study, the results (Figure 11) demonstrated that the saad extract was the best inhibitor for inhibition of alginate lyase activity $(86 \%)$ from local isolate of P.aeruginosa NA11, while other plant extracts show lower inhibition effect on enzyme activity.

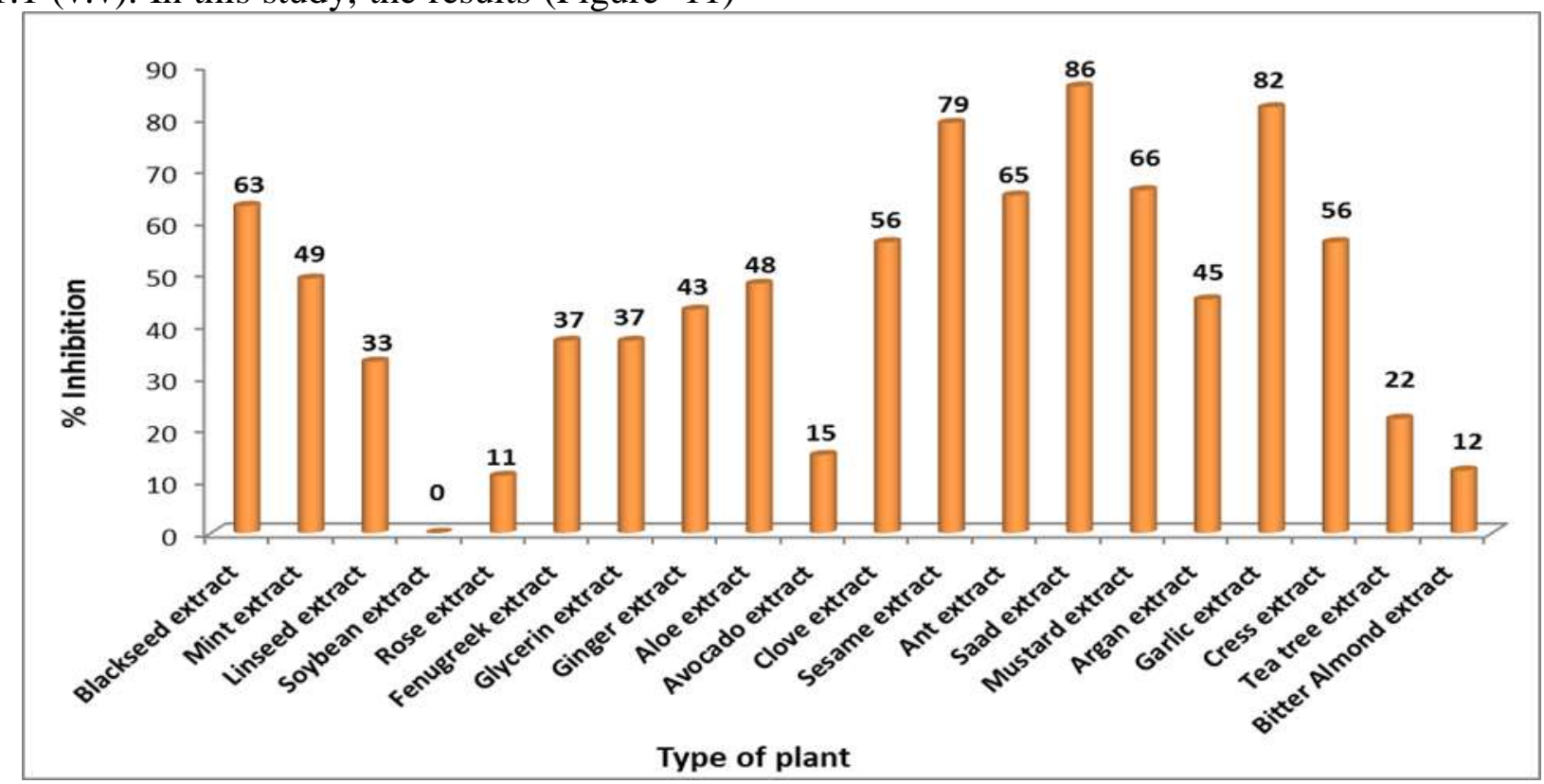

Figure 11. Impact of different plants extracts on alginate lyase enzyme activity

Saad plant is a multi-purpose plant which is widely employed around the world in traditional medicine to treat stomach ailments, wounds, boils and blisters. For this plant, a range of biological activities and pharmacological have been reported including antiinflammatory, anti-candida, antidiarrhoeal, antidiabetic, cytoprotective, antimicrobial, an- timutagenic, antioxidant, analgesic, antipyretic, cytototoxic and apoptotic. Previous phytochemical studies on saad plants revealed the presence of saponin, flavonoids, alkaloids, tannins, glycosides, starch, and furochromones, and numerous novel sesqui-terpenoids. Antibacterial activity of the saad plant extract showed remarkable activity against Gram- 
positive Staphylococcus aureus bacteria and Enterococcus faecalis. Another study demonstrated that the saad extract inhibitory effect on S.aureus, Salmonella enteritidis, P.aeruginosa and E.faecalis, due to its effect on their enzyme system (11).

\section{REFERENCES}

1. Abdalah, M.E., A.J.R. Al-Saady, M.H.A. ALBahrani, M.J. Al-Obaidi, and M.Y. Abd Al-Hussein, 2018. Cleavage of mucin and salivary agglutinin by partial purified protease from a native strain of Streptococcus mutans AN67. Journal of Global Pharma Technology. 10(06):404-410

2. Al-Shamary, E.I., 2018. Production of single cell oil from local fungal isolate. Iraqi Journal of Agricultural Sciences.49(4):527533

3. Al-Haidery, N.K.A. and R.M. Al-Muslih, 1989. Industrial microbiology. Higher education publisher. Baghdad university.688 page 4. Al-Jumaily, E.F. and R.I. Ali, 2015. Optimum conditions for alginase by Bacilllus circulans $\mathrm{R}$ isolate. IOSR Journal of pharmacy. 5: $42-47$

5. AL-Sa'ady, A.J.R. 2016. Determination of optimum conditions for xylanase production by Aspergillus niger using solid-state fermentation. Iraqi Journal of Science. 57(3): 22202227

6. Archana, K. and V. Jeyamanikandan, 2015. In vitro antibacterial, antioxidant and $\alpha$ amylase inhibition activity of medicinal plants.

J. Chem. Pharm. Res. 7(4):1634-1639

7. Aziz, G.M., Z.W. Abdulameer, and A.J.R. AL-Sa'ady, 2015. Extraction, partial purification and characterization of inulinase produced from Aspergillus niger AN20 by solid-state fermentation. Iraqi Journal of Biotechnology. 14(2): 111-122

8. Bedan, D.S., G.M. Aziz, and A.J.R. Al Sa'ady, 2014. Optimum conditions for $\alpha$ - amylase production by Aspergillus niger mutant isolate using solid-state fermentation. Current Research in Microbiology and Biotechnology. 2(4): 450-456

9. Beltagy, E.A., A. El-Borai, M. Lewiz, and S.A. Elassar, 2016. Purification and characterization of alginate lyase from locally isolated marine Pseudomonas Stutzeri MSEA04. Acta Biologica Hungarica. 305-317
10. Bradford, M. 1976. A rapid and sensitive method for the quantitation of microorganism quantities of protein using the principles of protein-dye binding .J.Anal. Biochem. 72 : 248- 254.

11. Dang, G. K., R.R. Parekar, S.K. Kamat, A.M. Scindia, and N.N. Rege, 2011. Antiinflammatory activity of Phyllanthus emblica, Plumbago zeylanica and Cyperus rotundus in acute models of inflammation. Phytotherapy Research 25(6), 904-908

12. Davidson, I.W., I W. Sutherand, and C.J. Lawson, 1976. Purification and properties of an alginate lyase from a marine bacterium. Biochem. J. 159: 707-713

13. Elahwany, A.M.D. and A.M. Elbora, 2012. Optimization of medium composition for extracellular alginate lyases of marine bacterium .afr.j.microbiol res. 6(10): 2403-2409

14. El-Sanshoury, A.E.R., E.R. Kenawy, A.A. Amara, S.F. Mohamed, A.F. Salama, and S. Kishk, 2018. Optimization of the culture medium using the Burman and Box-Behnken experimental designs for enhanced production of alginate by Azotobacter vinelandii. Journal of Biotechnology, Computational Biology and Bionanotechnology. 99(3): 185-196

15. Franklin, M.J. and D.E. Ohman, 1993. Identification of algf in the alginate biosynthetic gene cluster of Pseudomonas aerugino$s a$ which is required for alginate acetylation. J.Bacteriol. 175:5057-5065

16. Gacesa, P. and F.S. Wusteman, 1990. Plate assay for simultaneous detection of alginate lyases and determination of substrate specificity. Applied and Environmental Microbiology. 56(7): 2265-2267

17. Ghadam, P., F. Akhlaghi, and A.A. Ali, 2017. One-step purification and characterization of alginate lyase from $a$ clinical Pseudomonas aeruginosa with destructive activity on bacterial biofilm. Iran J Basic Med Sci. 20(5): 467-473

18. Hansen, J.B. and L.K. Nakamura, 1985. Distribution of alginate lyase activity among strains of Bacillus circulans. Applied and Environmental microbiology. 149(4): 1019-1021

19. Hussein, S.I., G.M. Aziz, R.M. Shanshal, A.L. Ghani, 2018. Determination the optimum conditions of laccase production from local isolate of Streptomyces $s p$. using solid state 
fermentation. Iraqi Journal of Agricultural Sciences. 49(4):685- 693

20. Kotil, B.A. , S. Manohar, and S. Lalitha, 2014. Media optimization for depolymerization of alginate by Pseudomonas aeruginosa AG LSL-11. International Letters of Natural Sciences Online. 19: 30-39.

21. Miller, G. L. 1959.Use of dinitrosalicylic acid reagent for determination of reducing sugar. Anal Chem. 31: 426-428

22. Shen, Q., B. Zhang, R. Xu, Y. Wang, X. Ding, and P. Li, 2010. Antioxidant activity in vitro of selenium-contained protein from these-enriched Bifidobacterium animalis 01 . Anaerobe. 16: 380-386

23. Tavafi, H. ; A. Abdi-Ali, P. Ghadam, and S. Gharavi, 2017. Screening of alginate lyase producing bacteria and optimization of media compositions for extracellular alginate lyase production. Iranian Biomedical Journal. 21(1): 48-56

24. Whitaker, J. R. 1972. Principle of enzymology for food science. Marcel Dekker Inc.New York., 5: 153-158

25. Zhua, Y., L. Wua, Y. Chena, H. Nia, A. Xiaoa, and H. Caia, 2016. Characterization of an extracellular bio-functional alginate lyase from marine Microbulbifer sp. ALW1 and antioxidant activity of enzymatic hydrolysates. Microbiological Research. 182: 49-58. 